\title{
STATUS OF SERUM IRON AND COPPER IN WOMEN TAKING ORAL CONTRACEPTIVE
}

\author{
F Hasanat ${ }^{1}$, PK Chakroborty ${ }^{2}$, A Hasanat ${ }^{3}$, SK Sharmin ${ }^{4}$, MB Mannan ${ }^{5}$, S Nargis ${ }^{6}$ \\ ${ }^{1}$ Dept of Biochemistry, Enam Medical College, Savar, Dhaka; ${ }^{2}$ Dept of Biochemistry, Mymensingh \\ Medical College, Mymensingh; ${ }^{3}$ Airport Health Office, Hazrat Shahjalal International Airport, Dhaka; \\ ${ }^{4}$ Ahsania Mission Cancer Hospital, Dhaka; ${ }^{5}$ Dept of Biochemistry, Nightingale Medical College, Dhaka; \\ ${ }^{6}$ Dept of Biochemistry, Ad-din Sakina Medical College, Jessore
}

\begin{abstract}
The oral contraceptive pill fulfills the great human need for birth control with unrivalled effectiveness. The pill can effectively prevent pregnancy and alleviate many menstrual disorders when used correctly. Many biochemical profiles of women taking oral contraceptives are disturbed due to metabolic alterations induced by its hormone content. The study was carried out in the Department of Biochemistry, Mymensingh Medical College, Mymensingh, during the period of July 2016 to June 2017 to evaluate the status of serum iron and copper in women taking oral contraceptive pills. For this study 120 agematched women were selected and grouped as 60 oral contraceptive user women and 60 non-oral contraceptive user women. Data were analyzed with the help of SPSS version 21. Mean $( \pm$ SD) level of serum iron and copper were $155.20 \pm 21.94 \mu \mathrm{g} / \mathrm{dl}$ and $157.6 \pm 14.75$ $\mu \mathrm{g} / \mathrm{dl}$ in oral contraceptive user women, while in normal healthy women the levels were $103 \pm 19.11 \mu \mathrm{g} / \mathrm{dl}$ and $126.28 \pm 17.18 \mu \mathrm{g} / \mathrm{dl}$ respectively. Serum iron and copper levels were significantly increased in oral contraceptive user group when compared with that of normal healthy group $(\mathrm{p}<0.001)$. From this study it can be concluded that there is significant association of serum iron and copper level with oral contraceptives.
\end{abstract}

Key Words: Oral contraceptives, Serum Iron and Serum Copper

\section{Introduction}

Contraceptives are devices or techniques that permit sexual union without resultant pregnancy1. In Bangladesh among the available modern methods of contraceptions, about $30 \%$ couples use oral contraceptives ${ }^{2}$. Combined oral contraceptives are highly effective, reversible and popular one3. The available and mostly used contraceptive in Bangladesh is the oral pill (Sukhi) containing estrogen and progestin ${ }^{4}$. Oral contraceptive pill stops ovulation by preventing the ovaries from releasing ovum. They also thicken cervical mucus making it harder for sperm to enter the uterus 5 . The major side effects of the oral contraceptive were found to be dreaded conditions like malignancy and thromboembolic cardiovascular diseases. Among the cardiovascular disorders, hypertension, myocardial infarction, hemorrhagic or ischemic strokes and venous thromboembolic conditions are common 6 . There has been interest in recent years about alterations in various metabolic processes and trace elements profiles associated with the use of oral contraceptives. Changes in lifestyle, environmental factors, dietary habits and active ingredients of hormonal agents have been known to affect status of micronutrients in humans ${ }^{7}$. Changes in tissue level 
$\underline{\text { Status of Serum Iron and Copper in Women Taking Oral }}$ or bioavailability of those elements in oral contraceptive users could play a significant role in health and in the pathogenesis of some disorders such as cardiovascular complications, the aging process, and certain cancers 8 .

Iron is an essential element for almost all living organisms. About $65 \%$ of the iron in the body is bound with hemoglobin in red blood cells and 4\% is bound with myoglobin molecules. Around 30\% of the iron in the body is stored as ferritin or hemosiderin in spleen, bone marrow and liver. Oral contraceptive pill initiates changes in iron level in body 9 . Disorders of iron metabolism are among the most common diseases of human and encompass a broad spectrum of diseases with diverse clinical manifestations, ranging from anemia to iron overload, and possibly to neurodegenerative diseases 10 .

Copper is one of the important trace elements and it is an essential co-factor for enzymes involved in metabolic reactions, angiogenesis, oxygen transport and antioxidant protection, including catalase, superoxide dismutase (SOD) and cytochrome oxidase ${ }^{11}$. There is an association between use of OCP and increase absorption of copper, resulting in increase of serum copper concentration. Increased level of copper in individuals on oral contraceptives may be related to a saturation of ceruloplasmin or a reduction in plasma ceruloplasmin level. Excess level of circulating copper may have adverse effect on liver. Use of oral contraceptive pill has been associated with alteration of serum copper level, which may even lead to hepatolenticular degeneration 12 . So, the present study was carried out to see the effect OCP on serum iron and copper, excess of which may cause many metabolic derangements leading sometime to dire consequences. Findings of this study may create awareness among the clinicians and gynecologists in prescribing iron and copper supplement in women taking OCP for contraception and thus help them in better management of those cases.

\section{Materials and Methods}

This cross-sectional study was carried out in the Department of Biochemistry, Mymensingh Medical College, and the subjects were collected from the Model Family Planning Clinic of Mymensingh Medical College Hospital during the period of July 2016 to June 2017. For this 60 apparently healthy married women with age ranging from 20 to 35 years taking no hormonal contraceptives for at least one year were selected as controls (Group A) and age- matched 60 married women taking oral contraceptive pill at least for last 03 months were taken as cases (Group B). Subjects having systemic illness like diabetes mellitus, hypertension, tuberculosis, and kala-azar were excluded from the study. Subjects with obesity, taking hormonal contraceptive pill other than combined estrogenprogesterone preparation and subjects taking any drugs containing iron and copper for last 6 months were excluded. Informed written consent was taken from each study subject and ethical approval for the study was obtained from the Ethical Committee of Mymensingh Medical College and Hospital.

Height in meter, body weight in kilogram and blood pressure were measured and Body Mass Index (BMI) was calculated. Serum iron was measured by colorimetric method using the test kit. In this method serum iron liberated from its complex with transferrin by the action of surfactants at acid $\mathrm{pH}$ is reduced to $\mathrm{Fe}^{2+}$ and reacts with batho-phenanthroline to produce a colored complex which is photometrically measured. Serum copper was estimated by colorimetric method with the 3,5-DiBr-PAESA stain in an acid solution ( $\mathrm{pH} 4.7)$. In this method copper is released from the ceruloplasmin protein and reduced. Afterwards the cuprous ion reacts with the 3,5-DiBr-PAESA stain, and forms colored complex which is measurel photometrically at $582 \mathrm{~nm}$. The color intensity is directly proportional to the copper ion concentration present in the sample. 
Data was analyzed with the help of SPSS version 21. Quantitative data were expressed as mean and standard deviation and comparison between groups was done by Student's unpaired ' $t$ ' test.

\section{Results}

In this study, mean $( \pm \mathrm{SD})$ age of controls (GrA) and cases $(\mathrm{Gr}-\mathrm{B})$ were $28.00 \pm 4.50$ years and $28.10 \pm 4.52$ years respectively, which showed no significant difference $(p>0.05)$. Mean $( \pm$ SD) BMI of controls and cases were $21.63 \pm 2.11$ and $21.67 \pm 2.11$ respectively, which showed no significant difference $(\mathrm{p}>0.05)$ (table-I).

Table-I: Demographic features of study subjects

\begin{tabular}{lccc}
\hline $\begin{array}{l}\text { Demographic } \\
\text { features }\end{array}$ & $\begin{array}{c}\text { Group-A (control) } \\
\text { Mean } \pm \text { SD }\end{array}$ & $\begin{array}{c}\text { Group-B (case) } \\
\text { Mean } \pm \text { SD }\end{array}$ & p value \\
\hline Age (years) & $28.00 \pm 4.50$ & $28.10 \pm 4.52$ & $0.904^{\mathrm{ns}}$ \\
$\mathrm{BMI}\left(\mathrm{kg} / \mathrm{m}^{2}\right)$ & $21.63 \pm 2.11$ & $21.67 \pm 2.11$ & $1.000^{\mathrm{ns}}$ \\
\hline
\end{tabular}

Data was expressed as Mean $\pm S D$ and comparison between groups was done by Student's unpaired ' $t$ ' test. $n s=$ not significant.

Table-II shows the level of serum iron and copper in study subjects. The study revealed that mean $( \pm \mathrm{SD})$ of serum iron level $(\mu \mathrm{g} / \mathrm{dl})$ in controls and cases were $103 \pm 19.11$ and $155.20 \pm 21.94$ respectively and it was significantly higher in cases $(p<0.001)$ compared to that of controls. Mean $( \pm \mathrm{SD})$ serum copper $(\mu \mathrm{g} / \mathrm{dl}) \quad$ was $126.28 \pm 17.18$ and $157.67 \pm 14.75$ in cases and controls respectively and it was significant in cases when compared with that of controls $(\mathrm{p}<0.001)$.
Table-II: Serum iron and copper levels of the study subjects

\begin{tabular}{lcc}
\hline $\begin{array}{l}\text { Biochemical } \\
\text { parameters }\end{array}$ & $\begin{array}{c}\text { Group-A (control) } \\
\text { Mean } \pm \text { SD }\end{array}$ & $\begin{array}{c}\text { Group-B (case) } \\
\text { Mean } \pm \text { SD }\end{array}$ \\
\hline Iron $(\mu \mathrm{g} / \mathrm{dl})$ & $103.43 \pm 19.11$ & $155.20 \pm 21.94<0.001^{*}$ \\
Copper $(\mu \mathrm{g} / \mathrm{dl})$ & $126.28 \pm 17.18$ & $157.67 \pm 14.75<0.001^{*}$
\end{tabular}

Data was expressed as mean Mean $\pm S D$ and comparison between groups was done by Student's unpaired ' $t$ ' test. $*=$ significant $(p<0.05))$

\section{Discussion}

The oral contraceptive pill fulfills the great human need for birth control with unrivalled effectiveness ${ }^{13}$. The pill can effectively prevent pregnancy and alleviate menstrual disorder when used correctly ${ }^{14}$. Many biochemical parameters of women taking oral contraceptives are disturbed due to metabolic alterations induced by its hormone content. Researches had been continuing for many decades to explore risk versus benefits of different contraceptive methods. The present study was designed to observe some biochemical alterations in women taking combined oral contraceptives containing $30-\mu \mathrm{gm}$ ethiny 1 estradiol and $150-\mu \mathrm{gm}$ levonorgestrel. Combined oral contraceptives (Sukhi) is the mostly used brand in rural community as it is distributed free of cost 15 . Therefore, metabolic alteration might be initiated earlier that go on silently without developing any overt clinical abnormality. On the contrary, long time use of hormones such as oral contraceptives can affect various metabolic pathways to such an extent that would cause detectable clinical abnormality 16 .

Iron is needed to make hemoglobin, the red colored substance in blood that carries oxygen. It has been argued that if less blood is lost each month, less blood needs to be manufactured. The combined oral contraceptive pills (COCPs) can increase the serum iron concentration by 
Status of Serum Iron and Copper in Women Taking Oral

reducing the menstrual period to 3 to 4 days and reduce the amount of blood loss in each menstrual cycle. OCPs also reduces the endometrial thickness that shortens the menstrual period. Several studies showed that the estrogen can increase the hepatic synthesis of transferrin (iron transporter protein) that lead to increase in the serum iron level17. In many instances, it is not entirely clear whether the effects observed are due to progesterone or estrogen. The observations of Briggs and Stanifond (1969), suggest that the rise of serum iron and iron binding protein in women on OCPs is due to progestogenic rather than the estrogenic compound of the preparation. It could be interesting to know whether the increase in serum iron concentration with oral contraceptive drugs is due to an increased efficiency of iron absorption or due to increased mobilization of iron from tissue stores.

The mechanism by which contraceptive steroids bring about changes in serum copper levels is not clearly understood. Carruthers et al. (1966) suggested that estrogen-induced synthesis of ceruloplasmin in the liver is responsible for the increase in serum copper levels. The estrogen component is mainly responsible for the increased level of serum ceruloplasmin while progesterone causes a less drastic rise. Estrogen acts as an inducer for synthesis of ceruloplasmin RNA templates causing subsequent increase in synthesis of the protein. For this reason, the increase in ceruloplasmin level cause an increase in serum copper concentration ${ }^{17}$. Another report (Briggs and Briggs, 1971) suggested that though estrogen administration alone increased serum copper values significantly, but progesterone administration had also shown relatively weaker effect on raising serum copper levels.

The present study showed significant alteration in serum iron and copper levels in oral contraceptive users. This study was done within the context of the facilities available to us. Our sample size was small due to limitation of time and fund. Considering the side effects, close biochemical monitoring and follow up must be emphasized for women on oral contraceptive.

It may be recommended to carry out a large scale prospective study with the application of modern sophisticated technology to elucidate alteration in biochemical parameters including other trace elements and organ function test which can give a conclusive decision.

\section{References}

1. Akinloye O, Adebayo TO, Oguntibej O, Oparinde DP, Ogunyemi DP. Effects of contraceptives on serum trace elements, calcium and phosphorus levels. West Ind Med J 2011; 60: 308-315.

2. Reatfield PK and Kamal N. Population and Family Planning in Bangladesh. J Pak Med Assoc 2013; 63(4): 73-82.

3. Nziavake MHL. Update on hormonal contraception. Cleveland Clin J Med 2007; 74(3): 186-198.

4. Hollander D. Bangladeshi women weigh variety of factors when choosing a contraceptive. Int Fam Plan Perspect 2003; 29: 1-3.

5. Kumar, Pratap and Malhotra.'Jeffcoate's Principle of Gynaecology' 7 th edn, Jaypee Brothers Medical Publishers Ltd, Kolkata, India. 2008; pp.798-809.

6. Obisesan KA, Adenaike FA, Okunola MA and Adenaike AA. Effects of oral contraceptives on total serum protein, albumins, globulins and cholesterol levels in Ibandan, Nigeria. WAJM 2002; 21: 3 .

7. Fallah S, Sani FV, Furoozrai M. Effect of contraceptive pill on the selenium and zinc status of healthy subjects. Contracept 2009; 80: $40-43$.

8. Olaniyan DA, Taylor S. Vitamin and antioxidant: The body fluid is not water. Nig Med $\mathbf{J}$ 2004; 16: 20-31. 
9. Wood RJ, Ronnenberg A, Shils ME, Shike M, Ross AC, Caballero B. Modern Nutrition in Health and Disease. In Lippincott's Illustrated Reviews Biochemistry, Lippincott Williams \& Wilkins 2005; 248-270.

10. Frazer DM and Anderson GJ. Intestinal iron absorption and it's regulation. Am J Physiol Gastrointest Liver Physiol 2005; 13: 631-635.

11. Gambling L, Andersen HS, McArdle HJ. Iron and Copper and their interaction during development. Biochem Soc Trans 2008; 36(6): 1258-1261.

12. Crews MG, Taper LJ, Ritchey SJ. Effects of oral contraceptive agents on copper and zinc balance in young women. Am J Clin Nutr 1980; 33: 1940-1945.

13. Elgee NJ. Medical Aspects of Oral Contraceptive. Ann Int Med 1970; 72: 409-418.
14. Suhl L, Sylvial, Yeage FB. Update on Oral Contraceptive Pills. Am Fam Physician 1999; 60(7): 2073-2084.

15. Amin R, Choudhury SR, Mariam AG, McCarthy J. Family planning in Bangladesh. Int Fam Plann Persp 1987; 13: 13-16.

16. Ramos D, Stanczyk R. Metabolic and endocrinological effects of steroidal contraception. 2009 viewed 14 April 2016, http://www.glown.com/help.

17. Moaed E, Al-Gazally, Melal M, Al-Jeborry, Ghufran, M. The effect of combined oral contraceptive devices on the oxidative stress, lipid profile and some trace elements in women sera. Med J Babylon 2010; 7(4): 490-498. 